\title{
A Lawyer Looks at Writ-Writing
}

\author{
Marshall W. Krause*
}

W EXPERIENCE WITH LEGAL PROBLEMS of prisoners began in 1957 not as civilly dead as law school had led me to believe. In succeeding years, I have become increasingly familiar with the genre, from the novice's first attempt to reacl out for the mystical process which will fly him over the walls, to the temporarily discouraged writer who informs me that if the facts he has related are insufficient for the purpose he will supply whatever facts are necessary, to the veteran researcher who claims freedom under Magna Carta and supports his claim with seventy pages of handwritten Latin citations. As hard and unrewarding as screening these petitions may be, each deserves attention; the sensitivity which we apply to the task will be a measure of our devotion to due process of law. Further, surety and regularity of process is the best defense agaimst repetitions of the "strip cell" treatment recently curtailed by a federal court in Califormia ${ }^{1}$ and the brutality which resulted in the resignation of the warden of the Arkansas State Prison. ${ }^{2}$

I

THE PRESENT SYSTEM

The writ of habeas corpus has proved to be the most useful and malleable legal remedy to test confinement and conditions of confinement in prisons. Other remedies, such as coram nobis ${ }^{3}$ and damage actions under the Federal Civil Rights Act, ${ }^{4}$ impose more technical requirements

*B.A., 1951, University of California, Los Angeles; LL.B., 1957, University of California, Berkeley; Staff Counsel, American Civil Liberties Union of Northern California.

${ }^{1}$ See Jordan v. Fitzliarris, 257 F. Supp. 674 (N.D. Cal. 1966). See also Berkeley Barb, Feb. 16, 1968, at 1, cols. 1 and 4; Truse, Dec. 15, 1967, at 75.

2 See Oakland Tribune, Jan. 30, 1968, at 2G, col. 3.

${ }^{3}$ See People v. Shipman, 62 Cal. 2d 226, 397 P.2d 993, 42 Cal. Rptr. 1 (1965); In re Nunez, 62 Cal. 2d 234, 397 P.2d 998, 42 Cal. Rptr. 6 (1965). A coram nobis petition is addressed to the trial court and asks that the judgment be vacated because some fact, not previously known to the defendant, has now come to light, and, if presented to the trial court, would have prevented pronouncement of judgment. A classic example is insanity of the defendant at the time judgment was pronounced. Excluded from coram nobis is the discovery of new facts bearing on the noninvolvement of defendant in the crime charged, even though the time to move for a new trial has passed and the facts were not previously known to the defendant. See People v. Shipman, 62 CaI. 2d 226, 397 P.2d 993, 42 Cal. Rptr. 1 (1965). The remedy in such a case is by habeas corpus. See In re Lindley, 29 Cal. 2d 709, 177 P.2d 918 (1947). Laches will apply to a coram nobis claimant to reject his claim if he unreasonably delays nuaking it after discovery of the crucial facts.

442 U.S.C. \& 1983 (1964). Upon the filing of an affidavit of poverty, Civil Rights Act suits may be filed and prosecuted in forma pauperis, 28 U.S.C. $\S 1915$ (1964). 
and are narrower in scope than habeas corpus. The habeas corpus applicant may petition state courts and, after state remedies have been tried and refused, federal courts to challenge the legality of his conviction, his sentence, his continued confinement without parole, the use of prior convictions against him, the place of incarceration when concurrent sentences are pending, penalities imposed for violation of prison rules, and his general conditions of confinement. But with a right must go a means for its enforcement. The Great Writ is only effective as a check on illegality if the cogent facts can be presented to courts and if courts will scrutinize such petitions and require hearings when their allegations or the undisputed facts of record do not negative a prima facie case.

In Cahifornia, unfortunately, the vast bulk of habeas corpus petitions do not receive careful attention from state trial courts because they must be filed within the county where the prison is located. ${ }^{\circ}$ Hence, a few small superior courts are vastly overloaded, while others are left untapped. Further, superior courts, in contrast to federal district courts, do not provide their judges with law clerks to screen and interpret the more obscure petitions. Most federal district courts do give careful attention to petitions, holding evidentiary hearings ${ }^{7}$ and appointing counsel where allegations of illegality are unresolved by the pleadings. These differences in approach account for much of the criticism concerning federal habeas corpus "interference" with state criminal procedures. The fact is that one sieve in California is considerably finer than the other, even though both are sifting for practically identical rejects.

The issues discussed in the preceeding papers pertain not so much to the way courts process prisoner petitions once they are filed, as to how prisoners may learn that their rights have been violated and how they can present the appropriate facts by the appropriate means to the appropriate courts. The answer under the current system is hit-and-miss, trialand-error, self-help. As Charles Larsen indicates, it is unfair to blame prisoner-litigants for the great volume of totally unmeritorious petitions filed with the courts. These litigants have no way of knowing whether their petitions contain legal merit. We may well analogize to the situation which would be presented if every person who thought he had a civil suit were required to first state his claim in a court pleading after which a lawyer would look over the claim to determine whether it had merit.

\footnotetext{
5 An outstanding judicial discussion of the offices of the Writ is found in Fay v. Noin, 372 U.S. 391 (1963), which case also illustrates the care taken to keep the remedy as flexible and powerful as circumstances require.

${ }^{6}$ CaI. Const. art. VI, $\$ 5$ (West 1954).

7 See Townsend v. Sain, 372 U.S. 293, 313 (1963).
} 


\section{A. Expert Help: Unavailable}

The simple fact is that expert help or advice in California is not available to the vast majority of the prison population once direct appellate rights are exhausted. ${ }^{8}$ This means that prisoners who wish to present certiorari petitions to the United States Supreme Court or to file collateral attacks on their convictions must do it themselves. ${ }^{9}$ Even though there is no interference with the constitutional requirement, under $E x$ Parte $B$ ull, ${ }^{10}$ that prisoners must be allowed time and materials to prepare and file petitions, it is questionable whether such a system comports with the general equal protection standards set forth with regard to appeals in Douglas v. California: ${ }^{11}$

There is lacking that equality demanded by the Fourteenth Amendment where the rich man, who appeals as of right, enjoys the benefit of counsel's examination into the record, research of the law, and marshalling of arguments on his behalf, while the mdigent, already burdened by a preliminary determination that his case is without merit, is forced to shift for himself. The indigent, where the record is unclear or the errors are hidden, has only the right to a meaningless ritual, while the rich man has a meaningful appeal. ${ }^{12}$

It is undoubtedly true that a rich man attacking his sentence collaterally can force a court to read the arguments of counsel before deciding the merits, but a poor man cannot. Of course, it is the poor man who is most likely to have had inadequate representation at his trial or the proceedings in which his guilty plea was accepted.

If we reject the notion that every indigent prisoner who wishes to complain about his conviction or the conditions of his confinement is entitled to the appointment of counsel, then we must deal with the prob-

8 See Douglas v. California, 372 U.S. 353 (1963), for the practice regarding indigent appeals prior to 1963.

' An occasional eloquent letter writer may find a "volunteer" attorney or be able to interest an organization providing legal services in his case. Once an attorney does volunteer for this public service he finds himself receiving many prisoner letters asking, pleading, threatening, and bribing for similar consideration. The American Civil Liberties Union of Northern California receives about fifty such letters per month in addition to approximately ten complete petitions sent in for "evaluation" each month.

10312 U.S. 546 (1941). For a discussion of other constitutional rights of expression in prison, see Note, The Right of Expression in Prison, 40 S. CAL. L. Rev. 407 (1967).

11372 U.S. 353 (1963).

12 Id. at 357-58. Chief Justice Traynor, speaking for the California Supreme Court in People v. Shipman, 62 Cal. 2d 226, 231, 397 P.2d 993, 996, 42 Cal. Rptr. 1, 4 (1965), echoes these standards by stating: "It is now settled that whenever a state affords a direct or collateral remedy to attack a criminal conviction, it cannot invidiously discrimmate between rich and poor." But the court adds: "[A]bsolute equality is not required; only "invidious discrimination' denies equal protection." 
lem of how the courts are to be made aware of meritorious claims. Charles Larsen suggests that there is terrible ineficiency in prison legal work. A potential litigant must be educated from the ground up in things as basic as literacy; several filings transpire before a prisoner acquires even a rudimentary understanding of the procedures.

Courts have said on many occasions that professional assistance is not needed in the preparation of habeas corpus petitions because the technicalities are minimal, and only a simple statement of the facts is required. ${ }^{13}$ Tlie following statement from a generally sympathetic district court opmion in Johnson v. Avery ${ }^{14}$ is typical:

Furthermore, the Court notes that a habeas corpus petition need not, and indeed should not, contain extensive legal citations. All that is required is a short, simple and intelligible statement of the facts on which the prisoner bases his claim for relief. ${ }^{15}$

Although this writer has himself stated as much in answers to many letters from prisoners, it is not correct. The prisoner is faced with a large number of facts and details which he is incapable of differentiating to determine which are essential and which are not. Without some insight into legal procedures and decided cases, the prisoner may bury the essential facts under a host of irrelevant details important to him because of his self-involvement. Even given an average education, there is no way for a prisoner to realize that the sentencing judge's failure to ask if he has any legal cause why judgment should not be pronounced is an essential fact ${ }^{16}$; nor can a prisoner be expected to know that the uncorroborated testimony of an accomplice is insufficient to convict under California law. ${ }^{17}$ Furthermore, when the prisoner is served with a return to his petition, he finds it filled with citations to cases and statutes which are clearly of some comfort to his opponent and of some discomfort to the prisoner unless he can find out what they mean.

\footnotetext{
13 Another prong to this argument is that rules of the federal district courts and of many state courts require that habeas corpus petitions be prepared on forms which probe for the essential facts. See, e.g., U.S. DIST. CT. N.D. CAI. R. 28. These forms do require a statement of essential facts such as the crime for which the petitioner was convicted and the name of his counsel, but the essential questions, such as, "In what way were you deprived of due process of law?" still require legal sophistication. In practice, prisoners using these forms generally fill them out with large appendices incorporated by reference which contain the same kinds of argumentation which would normally be found in petitions filed without the aid of the form.

14252 F. Supp. 783 (M.D. Tenn. 1966), rev'd, 382 F.2d 353 (6th Cir. 1967). Sec text accompanying notes 22-28 infra.

15 Id. at 787.

16 See Cat. Pen. Code $\$ 1200$ (West 1956).

17 See Cat. Pen. Code $\S 1111$ (West 1956).
} 


\section{B. Self-Help: Difficult if Not Impossible}

For these very practical reasons, most prison litigants turn either to a law library (which can include a personal cache of legal opinions supplemented by a few volumes in the prison library) or to a "jailhouse lawyer" for assistance. It has generally been held, for the reasons stated above in the Johnson case, that there is no constitutional right for prisoners to have access to law books. ${ }^{18}$ This writer feels that such reasoning proceeds on the faulty premise that legal learning is irrelevant to habeas corpus petitions. It ignores the absence of a justifying state interest in preventing a prisoner from having access to a reasonable number of law books. If a prisoner has money to purchase his own law books, there would seem to be no basis for preventing these from being placed in the prison hbrary. If the prison already has law books, there would seem to be no justification for preventing access to these books. ${ }^{19}$ There is presently pending in the Ninth Circuit an action under the Federal Civil Rights Act challenging the California Department of Corrections regulation which bars "personally owned law books ... [and] personally owned copies of opimions and decisions."20 In addition, the challenged regulations specify a small number of law books which are to be available in prison hbraries with the stipulation that any books not on the selected list be destroyed. ${ }^{21}$ Books as basic as Title 28 of the United States Code (containing federal habeas corpus statutes) are not on the hist. A temporary restraining order in Geldern v. McGee $e^{22}$ presently prevents destruction of existing books.

The question of assistance fron other inmates is the subject of an interesting opinion in Johnson v. Avery. ${ }^{23}$ Johnson had been sentenced to eleven months in solitary confinement for preparing legal papers for other prisoners in violation of a Tennessee prison rule. He challenged his confinement by habeas corpus. The district court wrote:

[W] ithout the assistance of some third party, many prisoners in the state pemitentiary would be totally incapable of preparing an intelligible petition, letter or request, on their own behalf ... [The same considerations] ... make it impossible for [a prisoner] to draft a letter which would be sufficient to arouse an attorney's interest. Furthermore, few indeed would be the lawyers who would volunteer to represent such prisoners, the great majority of whom are totally indigent.

For all practical purposes, if such prisoners cannot have the assis-

${ }^{18}$ See text accompanying note 20 infra.

19 Of course, prisoners especially confined because of infractions of prison rules might also have their access to the library restricted.

20 Geldern v. Lynch, Civil No. 45878 (N.D. Cal., filed Apr. 3, 1967).

21 Dept. of Corrections Administrative Manual, II 330.04, .041, .044, .045.

22 Civil No. 45878 (N.D. Cal., filed Mar. 10, 1967).

23252 F. Supp. 783 (M.D. Tenn. 1966), rev'd, 382 F.2d 353 (6th Cir. 1967). 
tance of a 'jail-house lawyer,' their possibly valid constitutional claims will never be heard in any court. ${ }^{24}$

The district court held that Johnson was entitled to habeas corpus because the state prison officials were interfering with the right of a prisoner to have someone prepare petitions "acting on his behalf" within the meaning of section 2242 of title 28 of the U. S. Code. ${ }^{25}$ The circuit court reversed ${ }^{26}$ but did not attempt to solve the problems so cogently described by the district court judge. The circuit court held that the words "or by someone acting in his behalf" from section 2242 must be himited to the signing and verification of a petition and did not include the preparation of a petition. It further held that the district court's opimion in effect admitted Johnson to the practice of law in the State of Tennessee which was beyond the competence of the federal courts. The Court stated:

Indeed, we believe that no favor is granted to other prisoners by allowing them representation by one untrained in the complexities of postconviction procedure and unrestrained by the values, ethics, and traditions of the bar. It takes little imagination to recognize possibilities of conflict of interest in allowing one who is a convicted murderer, rapist or burglar, serving a long sentence, to represent prisoners who have possible meritorious claims. ${ }^{27}$

What the circuit court said has some truth. But the fact remains that expert advice is nonexistent and jailhouse lawyers will continue to be utilized by those prisoners who are inexperienced in petitioning courts. ${ }^{28}$ Not unnaturally, a semi-hterate prisoner prefers the aid of a convicted inurderer to no help at all. Instead of worrying over competition with members of the Tennessee Bar, the circuit court might have provided some reasoning toward solution of the dilemma properly recognized by the district court.

II

SUGGESTIONS TOWARD A SOLUTION

Cliarles Larsen believes that the number of frivolous petitions filed would be greatly reduced if prisoners could have an objective evaluation of their chances before filing their petitions. Obviously, this objective evaluation inust be done by someone whom the prisoner can trust; even so, the process will filter out only a portion of the frivolous petitions. An

24252 F. Supp. at 784.

2528 U.S.C. \& 2242 (1964).

28382 F.2d 353 (6th Cir. 1967).

27 Id. at 357 .

28 See Note, Legal Services for Prison Inmates, 1967 Wrs. L. REV. 514. 
approach which has been tried and found effective in Wisconsin is the assignment of a law student as legal intern within the prison system. ${ }^{29}$ This is a help, if not a solution. A law student, however, will lack the "feel" for judicial error that an experienced practitioner has; noreover, it will take him a considerable time to learn the considerations applicable to habeas corpus petitions and related remedies.

What is needed is a state public defender, expert in handling appeals from criminal convictions-just as the Attorney General is expert in handling the prosecution's case in sucl appeals-who will also have jurisdiction to investigate complaints from prisoners and file collateral attacks in appropriate cases. If adequately staffed, a state public defender's office could assume much of the burden now carried by a disproportionately small number of members of the California bar and at the same time ease the judicial load by providing a screening service to explam to prisoners why their complaints do not appear to entitle them to legal relief.

It is surprising that no one has studied the therapeutic value of writwriting; it is possible that writ-writing provides an outlet for prisoners who would otherwise become disciplinary problems. On the other hand, perhaps writ-writing may allow a frustrated prisoner to reinforce his feeling that there was not only no justice in his case but that justice is a commodity sold to the highest bidder and unattainable by the indigent. In these circumstances he may ignore the reasons for his confinement and be denied the benefit of seeing himself clearly. Exploration of these issues should not be a difficult task.

Prisons have not been a notable success as a means to overcome antisocial conduct. Indeed, a very strong case can be made for the statement that only weeds and artificial plants can grow within their walls. We must take care to nurture whatever green shoots of justice now and then sprout froin between the rocks so that even the guilty are not without hope.

29 See Kimball, Correctional Internships-A Wisconsin Experiment in Education for Professional Responsibility, $18 \mathrm{~J}$. OF LEGAI EdUc. 86 (1965). 